\title{
Predicting Mango Sudden Decline Due to Ceratocystis fimbriata Under a Changing Climate
}

\author{
Amna M. Al-Ruheili', Alaba Boluwade ${ }^{2,3}$ and Ali M. Al-Subhi ${ }^{1,4}$ \\ (1) Department of Plant Science, College of Agriculture and Marine Science, Sultan Qaboos University, \\ Muscat, Oman, Email: alruheli@squ.edu.om; (2) Department of Soil, Water and Agricultural Engineering, \\ College of Agriculture and Marine Science, Sultan Qaboos University, Muscat, Oman; \\ (3) Lazaridis School of Business and Economics, Wilfrid Laurier University, Waterloo, Canada; \\ (4) Oman Animal and Plant Genetic Resources Centre, Ministry of Higher Education, \\ Research and Innovation, Muscat 112, Oman.
}

\begin{abstract}
Al-Ruheili, A.M., A. Boluwade and A.M. Al-Subhi. 2021. Predicting Mango Sudden Decline Due to Ceratocystis fimbriata Under a Changing Climate. Arab Journal of Plant Protection, 39(3): 215-223. https://doi.org/10.22268/AJPP-039.3.215223 Mango fruit trees are an important fruit crop due to their high value. Mango sudden decline (MSD) is a major disease that threatens mango trees in Oman and worldwide. The objective of this study was to identify those areas in northern Oman in which Ceratocystis fimbriata (a plant fungal pathogen causing MSD) may establish itself under various climate change scenarios. The MaxEnt model used in this study was based on data for the period 1970-2000 and then projected to future climate periods. This study modeled the future distribution of $C$. fimbriata for 2021-2040, 2041-2060, 2061-2080, and 2081-2100 climatic scenarios. Fifteen affected locations and seven bioclimatic variables were investigated in this study. The model showed values between 0.896 and 0.913 (habitat suitability) which represented a good model outcome. The jackknife test showed that the mean diurnal range in temperature, precipitation of the driest month, and elevation contributed to $C$. fimbriata distribution. From 2021 through 2040, a total area of $1,889 \mathrm{~km}^{2}$ was found to be highly suitable for C. fimbriata in Northern Oman. Compared with the 2021-2040 period, the poorly suitable area would increase in both 2041-2060 and 2081-2100 periods. The moderately suitable regions for $C$. fimbriata would decrease under all scenarios investigated. However, the total area of the suitable areas, with all scenarios, would increase, except during the 2041-2060 period. This research offers a tool to better manage and prevent the possible Ceratocystis blight ( $C$. fimbriata) and bark beetle (Hypocryphalus mangiferae) invasions under future projected climatic scenarios.

Keywords: Mango sudden decline (MSD), "Ceratocystis fimbriata", bioclimatic variables, climate change, Sultanate of Oman, Maxent.
\end{abstract}

\section{Introduction}

The agricultural sector is an important component of the global economy. For instance, $65 \%$ of jobs and earnings in Africa are agriculturally based (Pretty et al., 2011). Therefore, the loss of agricultural production resulting from pests and diseases is a major concern for every farmer and any agriculture-based economy. According to Godfray et al. (2010), the sustainability of the agricultural yield relies on the continuous management of pests and diseases to ensure profitable productivity. The mango tree (Mangifera indica) is grown in many continents, including Asia, South America, and Africa, and has high economic value (Arauz, 2000). Mangoes are also one of the most significant perennial fruit crops in the Sultanate of Oman (hereafter: Oman). In 2004, in the Al Batinah agricultural region, orchards planted with mango reached around 2500 ha, with total fruit production estimated at $8600 \mathrm{t}$ (Al-Adawi et al., 2006).

However, in 1999, mango sudden decline (hereafter: MSD) appeared in Oman. Following the onset of this disease, more than $60 \%$ of mango trees were affected in northern Oman in the Al Batinah region (Al-Subhi et al., 2006). MSD resulted in the loss of over 200,000 mango trees, which represented $13 \%$ of all the mango trees in the region (Al-Adawi et al., 2006). MSD is a fungal disease that attacks the mango tree's vascular system and results in a quick decline or sudden death. The disease becomes a serious threat to mango trees throughout the entire region. The major symptoms of MSD are trunk secretion and wilting and the browning of leaves on single branches. In one study, most of the affected trees died six months after symptoms appeared (Pereira et al., 2019). Different fungi have been reported to be associated with MSD. Pathogens such as Ceratocystis blight (Ceratocystis fimbriata, $C$. manginecans, $C$. omanensis, and Lasiodiplodia theobromae) are the fungi isolated from MSD mango trees and were most commonly found in Oman and Pakistan. The bark beetle (Hypocryphalus mangiferae) is the vector responsible for spreading the pathogens among mango trees (Al-Adawi et al., 2003). According to Al-Adawi et al. (2006), $H$. mangiferae played a significant role in the dispersal of the mango sudden decline pathogen. Many countries around the world, including Iran, Australia, Egypt, India, the USA, Brazil, and Korea, have associated MSD with the fungal pathogen Ceratocystis sp., resulting in the wilting and death of their mango trees (Saeed et al., 2017). Many other countries around the world reported similar effects of MSD. For example, Pakistan considered MSD as the most destructive disease for mango trees, and 10-28\% of mango trees were reported in Punjab to be affected by the disease, resulting in heavy economic losses for mango producers (Hassan \& Nazami, 2017).

https://doi.org/10.22268/AJPP-039.3.215223

(C) 2021 Arab Society for Plant Protection الجمعية العربية لوقاية النبات 
The climatic variation appears to play a significant role in the distribution of both pests and diseases around the world. According to Rosenzweig et al. (2010), climate change has a huge impact on agricultural crops and insect populations in both natural ecosystems and agroecosystems. Some studies have assessed the impact of climate change on bioclimatic conditions and their role in increasing the geographical distribution of pests and diseases. For example, Biber-Freudenberger et al. (2016), conducted a study to model the pest distribution for tomato leafminer (Tuta absoluta), mango fruit fly (Ceratitis cosyra), and oriental fruit fly (Bactrocera) to estimate the extent and change of pest habitats across Africa under various future climate change scenarios. The authors concluded that there is slightly increasing habitat suitability for the three pests on the entire African continent. Climatic conditions also contribute to the distribution of the H. mangiferae (Rossetto \& Ribeiro, 1990). $H$. mangiferae is the vector for MSD infection. The mango bark beetles have the capability to spread the fungal structures over long distances and may infect other parts of the plant and remain in the soil, which can result in the loss of an entire mango planted area. Once the mango trees show symptoms, then the beetle serves as a proxy for disease spread. There is no information available on the spatial distribution of mango in Oman. Therefore, this study provided a proxy of possible suitable habitat for mango and the disease as well. In other words, understanding these environmental factors is crucial for forecasting the disease distribution and its patterns in efforts to develop informed management practices. Various climate change scenarios and models are available for different anthropogenic $\mathrm{CO}_{2}$ emission forecasts, and these help researchers generate projections for the distribution of certain diseases in anticipation of possible future outbreaks (Collins et al., 2013). Several species distribution studies have been conducted to model pest and disease habitat suitability under future climate change scenarios. For instance, the potential distribution of pests and diseases in Asia, North America, and several European countries has already been modeled (De Meyer et al., 2010; Solhjouy-Fard et al., 2013). However, fewer modeling approaches have been constructed for disease projection with a focus on Oman (da Silva Galdino et al., 2016). There is, therefore, a need to assess the impact of climate change on pest and disease distribution in order to estimate the potential losses of agricultural products. Currently, the methods to control MSD involve using grafting methods in which an exotic scion is grafted on a local plant rootstock. This is because MSD (through $H$. mangiferae) is found more on local varieties than on the exotic grafted varieties (Al-Adawi et al., 2006). Because MSD issues in Oman have not yet been resolved and climate change is a fact, the impact of climate change on this mango disease needs to be assessed. This study aimed to project various climate change scenarios in the context of MSD disease and to assess the disease's future distribution and patterns to help decision-makers develop informed management practices and assist in planning the further expansion of agricultural species and potential associated risks that may arise.

This study used maximum entropy species distribution modeling (Maxent), which is based on correlative ecological niche models between species occurrences and environmental variables to generate maps of potential species distribution by fitting a probability distribution for species occurrence in a geographic area. The niche-based model is used to describe the ecological suitability of a space and to generate a geographic area of the predicted presence of the species that satisfies the fundamental niche conditions necessary for those species and their potential distribution (Phillips et al., 2006). Several studies have demonstrated the use of this model in predicting pest and disease distribution. For example, given future climate conditions scenarios, the forest in the interior of the western US is predicted to see a $27 \%$ increase by 2050 of the mountain pine beetle (Evangelista et al., 2011). As climate change occurs, there is a need to predict the potential MSD distribution under different climate change scenarios in order to better select appropriate growing areas for future mango cultivation and production. Therefore, the primary objective of this study is to analyze the potential suitable areas for the establishment of C. fimbriata in northern Oman.

\section{Materials and Methods}

\section{Study area}

Oman (Figure 1) is an arid country in the Arabian Peninsula with a population of almost 5 million as of 2019 (World Bank, 2020). The total land area is more than $309,500 \mathrm{~km}^{2}$ (McDonnell, 2016). The country can be divided into three main land surface areas: coastal plains, deserts, and mountains (McDonnell, 2016). With 11 different administrative governorates (Figure 1), the country's main agricultural area is located in the Al-Batinah, Musandam Peninsula, interior oases, high plateaus of the eastern region, and Dhofar region (Al-Adawi et al., 2003). According to AlAdawi et al. (2003), the climate is generally hot and humid and hot \& dry in the coastal areas and hot and dry in the interior areas. According to McDonnell (2016), the average annual precipitation for the entire country, interior and mountainous \& coastal areas is around $100 \mathrm{~mm}, 20 \mathrm{~mm}$, and $400 \mathrm{~mm}$, for the three regions, respectively. This rain occurs during the winter months (November-April) in the north and interior regions of Oman, whereas there is a monsoon summer season (June-September) experienced in the southern (Dhofar) region of Oman (Al-Adawi et al., 2003). The average temperature in the northern, interior, and Salalah plain is in the range $20-28^{\circ} \mathrm{C}, 19-26^{\circ} \mathrm{C}$ and $20-27^{\circ} \mathrm{C}$, in the three regions, respectively (MRMWR, 2008). Evaporation in the interior, Al-Batinah coast, and Salalah plain is estimated to be $3000 \mathrm{~mm}, 2100 \mathrm{~mm}$, and $1700 \mathrm{~mm}$, respectively (MRMWR, 2008). Due to the vast area of land dominated by mountains, the total area under agricultural production is limited. As of 2004, the cultivated land area was around 58,800 ha with annual and perennial crops around 12,700 ha and 46,000 ha, respectively (Al-Adawi et al., 2003). According to the Ministry of Agriculture and Fisheries (2014), approximately $7 \%$ of the total land area in Oman has soil that can support agriculture. Oman's cropping system is mainly fruit trees including date palms, forage (i.e. alfalfa \& Rhodes grass), and vegetable crops, which 
constitute $45 \%, 30 \%$, and $17 \%$ of the cultivated area, respectively.

\section{Pest species and presence records}

The disease incidence data caused by $C$. fimbriata was obtained from the literature (da Silva Galdino et al., 2016) related to a total of 15 unique affected locations in the northern part of Oman (Figure 1). The strength of Maxent is its ability to make predictions with small sample size as reported in the literature (Anderson \& Gonzalez, 2011). The collected data points represent the locations of the mango trees (Figure 1) infected with MSD that showed symptoms, including branch death, wilting leaves, and bark discoloration (da Silva Galdino et al., 2016). The black outlined area shown in the right panel of Figure 1, is the area used for this study.

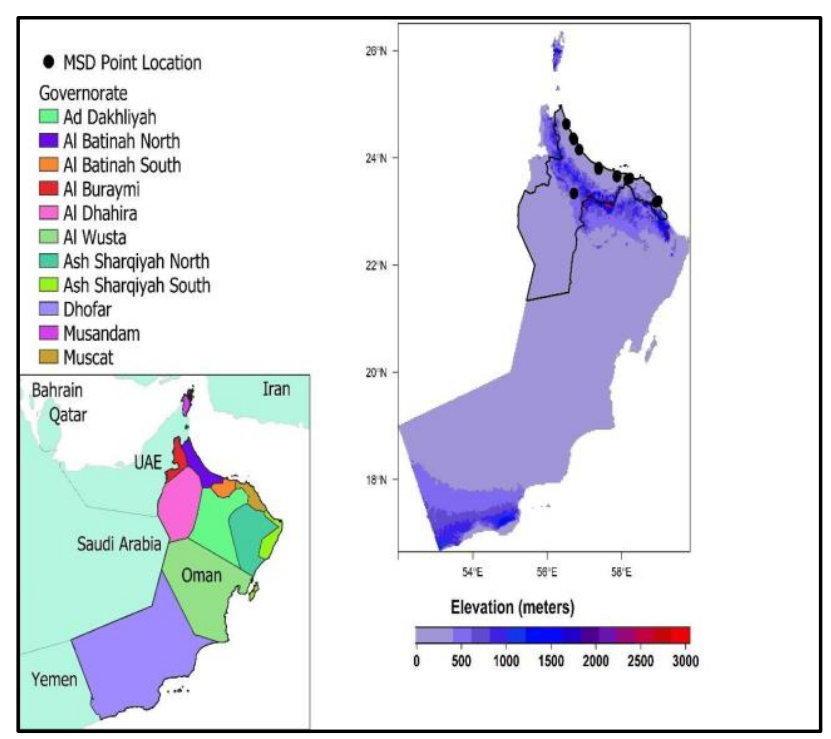

Figure 1. Sultanate of Oman map showing the mango sudden decline (MSD) locations reported by da Silva Galdino et al. (2016). The black outlined polygon shown to the top right represents the study area.

\section{Environmental variables}

To determine the future distribution of MSD under different climate scenarios, the study used datasets of future climate from the WorldClim data portal (https://www.worldclim.org/data/index.html). The future bioclimatic data were obtained from WorldClim v2.1, which was downscaled using CMIP6 at 2.5 minutes $(4.5 \mathrm{~km})$ spatial resolution. The climatic data was subject to nine Global Climate Models (GCMs) and four Shared Socio-Economic Pathways (SSP6-8.5) for the following periods: 1970-2000 (current \& training period), 2021-2040, 2041-2060, 20612080, and 2081-2100 and were available in a Geotif raster format (Eyring et al., 2016). This paper used ssp585 and the climate conditions that were represented by 19 bioclimatic variables. The 19 bioclimatic variables were extracted from the Geotif using statistical software. After the 19 bioclimatic variables for the eight models (not shown) were extracted, the average of each bioclimatic variable was calculated and used as an input for the model. The environmental variables derived from the WorldClim repository have been widely used in the prediction of the potential distribution of species as they are influenced by the changes in temperature and precipitation. As a result, these variables contribute to the ecology of species, which helps in explaining the predicted future distribution of species resulting from climate change (Zhang et al., 2016).

This study considered the use of 20 environmental variables. Eleven of these variables were derived from the monthly temperature, while eight were derived from the monthly precipitation and digital elevation model. The decision to include seven bioclimatic variables in this study was based on the earlier study conducted by da Silva Galdino et al. (2016) to model the distribution of MSD in Oman. For the current disease distribution (training datasets), bioclimatic variables in the WorldClim database (version 1.4) included the information of 19 bioclimatic variables from 1970 until 2000. The highly correlated variables were removed at 0.8 and seven climatic variables were relevant to MSD distribution (Table 1). Accordingly, for the periods 2021-2040, 2041-2060, 2061-2080, and 2081-2100, this study incorporated these seven bioclimatic variables: mean annual temperature (bio1; ${ }^{\circ} \mathrm{C}$ ); precipitation of the coldest quarter (bio19; mm); seasonal precipitation (CV) (bio15); precipitation of the driest month (bio $14 ; \mathrm{mm}$ ); elevation $(\mathrm{m})$; precipitation of the wettest month (bio13; mm); and mean diurnal range in temperature (bio2; ${ }^{\circ} \mathrm{C}$ ). However, bio15 and bio13 appear to make a nonexistent to minimum contribution regarding the future distribution of MSD.

\section{Model and analyses}

This study used Maxent v.3.3., which was obtained from the web portal of Princeton University at http://www.cs.princeton.edu/. The software can forecast the extent and map the possible species distribution based on maximum entropy or environmental variables. The model uses climatologic variables in combination with species' locations to predict the species' capability of establishing itself in new areas. Maxent has the capability in producing various suitability indices ranging between 0 for unsuitable areas and 1 for highly suitable areas. Maxent yields in two assessment models: the area under the receiving operating characteristic (ROC) curve (AUC) and jackknife testing 17]. This study utilized Maxent to forecast the future distribution of MSD because of Maxent's ability to work with records of few locations at the same time (Pearson et al., 2007).

Maxent uses AUC in assessing the model's performance, which is considered an excellent index indicator for the model's performance. At the same time, the ROC is used to assess the AUC model's performance through thresholding (Prabhulinga, 2017). The assessment of the AUC model's performance employs five categories: not suitable $(0.5-0.6)$, low suitability $(0.6-0.7)$, moderate suitability (0.7-0.8), suitabile (0.8-0.9), highly suitable (0.91) (Swets, 1988). The AUC values closer to 1, represent the good performance of the model. Therefore, low values of AUC are considered unreliable and vice versa. 
Table 1. Environmental variables considered for the $C$. fimbriata Niche model and the average percent contribution of environmental variables in the mango sudden decline best Maxent model.

\begin{tabular}{|c|c|c|c|c|c|c|c|c|c|c|}
\hline \multirow{2}{*}{$\begin{array}{l}\text { Period } \\
\text { Scenarios } \\
\text { Variables }\end{array}$} & \multicolumn{2}{|c|}{ 1970-2000 } & \multicolumn{2}{|c|}{$2021-2040$} & \multicolumn{2}{|c|}{$2041-2060$} & \multicolumn{2}{|c|}{ 2061-2080 } & \multicolumn{2}{|c|}{ 2081-2100 } \\
\hline & $\begin{array}{c}\% \\
\text { Cont.* }\end{array}$ & PI* & $\begin{array}{c}\% \\
\text { Cont. }\end{array}$ & PI & $\begin{array}{c}\% \% \\
\text { Cont. }\end{array}$ & PI & $\begin{array}{c}\% \\
\text { Cont. }\end{array}$ & PI & $\begin{array}{c}\% \% \\
\text { Cont. }\end{array}$ & PI \\
\hline $\begin{array}{l}\text { Mean annual temperature } \\
\text { (biol; }{ }^{\circ} \mathrm{C} \text { ) }\end{array}$ & 0.5 & 7.4 & 0.7 & 14.7 & 2 & 26.7 & 2.2 & 37.8 & 4.3 & 51.7 \\
\hline $\begin{array}{l}\text { Precipitation of coldest quarter } \\
\text { (bio19; mm) }\end{array}$ & 5.2 & 27.7 & 0.7 & 1.3 & 13.1 & 1.1 & 0.1 & 0.2 & 0.2 & 0.1 \\
\hline $\begin{array}{l}\text { Precipitation seasonality (CV) } \\
\text { (bio15) }\end{array}$ & 0.1 & - & - & - & - & - & - & - & - & - \\
\hline $\begin{array}{l}\text { Precipitation of driest month } \\
\text { (bio14; mm) }\end{array}$ & 36.7 & 13.6 & 31.4 & 15.6 & 32 & 35.6 & 37.5 & 38.8 & 37.5 & 32.5 \\
\hline $\begin{array}{l}\text { Elevation } \\
(\mathrm{m})\end{array}$ & 4.2 & 6.9 & 15.1 & 8.4 & 4.6 & 7.1 & 7.1 & 9.4 & 9.3 & 12.5 \\
\hline $\begin{array}{l}\text { Precipitation of wettest month } \\
\text { (bio13; mm) }\end{array}$ & 0.1 & 0.1 & - & - & 0.3 & 15 & 0.1 & - & 0.3 & - \\
\hline $\begin{array}{l}\text { Mean diurnal range in temperature } \\
\left(\text { bio2; }{ }^{\circ} \mathrm{C}\right)\end{array}$ & 53.3 & 44.3 & 52 & 59.9 & 48 & 14.4 & 53 & 13.7 & 48.5 & 3.1 \\
\hline
\end{tabular}

*\% Cont. $=\%$ Contribution; $\mathrm{PI}=$ Permutation importance

The jackknife test is used to assess the leading bioclimatic variables and map the possible distribution of $C$. fimbriata. The jackknife test is built-in to the software used to calculate the habitat suitability curves of each variable; it is also used to assess each climatic variable's contributions to the habitat model (Li et al., 2016). More information on this model's modeling approach can be found in Philips and Dudik (2008).

\section{Evaluation of the model performance}

Because the data was limited, this study used crossvalidation for 15 replications with a threshold at 10 percentile training presence (Shcheglovitova \& Anderson, 2013). The following parameters such as auto-features and regularization multiplier used the default settings. The default parameter settings were used because they are effective and are suitable for a wide-range of species occurring data sets. 15 replicated runs were used to get the output of the average logistic. The output of the replication is used to estimate the likelihood of the presences indices per category between 0 (not likely to occur) and 1 (most likely to occur) (Phillips et al., 2006; Phillips \& Dudík, 2008).

AUC was used to estimate the goodness of fit under the ROC curve, where the highest value indicated the best performer. The jackknife, the percentage contribution, and the permutation importance were used to estimate the most important environmental variables governing MSD distribution. Response curves were generated in Maxent and were used to indicate the relationships between predicted probabilities of the presence of the disease with respect to the variations within each environmental variable.

\section{Results}

Bioclimatic variables contribution and Maxent
performance C. fimbriata forecasting during the 2021-2040 climatic scenario was found to be AUC mean $=0.913$. The outcomes of the model presented that some of the designated seven bioclimatic variables of $C$. fimbriata showed the distribution of MSD for the period 2021-2040 very well. Among the seven bioclimatic variables, three contributed significantly to the disease occurrence such as bio 2 with $52 \%$ contribution, bio14 with $31.4 \%$ contribution, and elevation with $15.1 \%$ contribution. In contrast, the distribution of the bioclimatic variable of $C$. fimbriata for the period 2041-2060 was for bio 2 with $48 \%$ contribution, bio14 with $32 \%$ contribution, and elevation with $4.6 \%$ contribution. The bioclimatic variables' distribution of C. fimbriata for the period 20612080 were for bio 2 with $53 \%$ contribution, bio14 with $37.5 \%$ contribution, and elevation with $7.1 \%$ contribution. For the period 2081-2100, the bioclimatic variables' contribution to MSD distribution were for bio2 with $48.5 \%$ contribution, bio14 with $37.5 \%$ contribution, in addition to elevation with 9.3\% contribution (Table 1 ).

The jackknife test for the period 2021-2040 showed that bio2, bio13, bio14, and elevation were the main variables (Figure 2), and in terms of permutation the main variables were bio2 with $59.9 \%$, bio14 at $15.6 \%$, and elevation at $8.4 \%$ contribution. These figures demonstrate that temperature and precipitation play a significant role in forecasting the possible dispersal of $C$. fimbriata. Based on the species response curves acquired, $C$. fimbriata prefers a mean diurnal range in temperature, limited precipitation, and moderate elevation. 


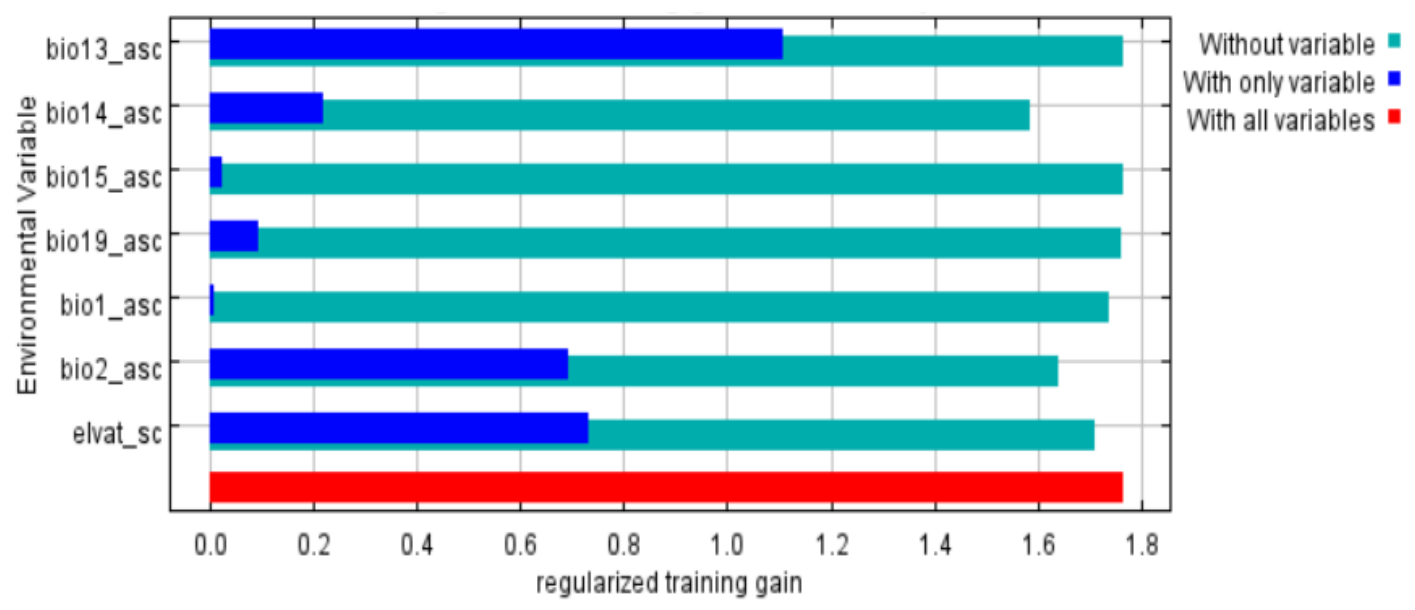

Figure 2. Jackknife test of environmental variable importance for $C$. fimbriata. Y-axis represent the seven environmental variables in ASCII raster format (bio1 = Annual Mean Temperature; bio2 = Mean Diurnal Range (Mean of monthly (max temp - $\min$ temp)); bio13 = Precipitation of Wettest Month; bio14 = Precipitation of Driest Month; bio15 = Precipitation Seasonality (Coefficient of Variation); bio19 = Precipitation of Coldest Quarter).

The mean AUC values showed in Table 2 for $C$. fimbriata in the future periods (2041-2060, 2061-2018, and 2081-2100) performed well, indicating trustworthy predictability, and the AUC values of $0.913,0.896$, and 0.907 , respectively, were considered high. The model outcome shows that the simulations can be used to analyze the impact of climate change on the distribution of $C$. fimbriata in Oman.

Table 2. AUC values when modeling C. fimbriata distribution of various climate change scenarios for three future periods (2041-2060, 2061-2080, and 2081-2100; 15 replicated runs).

\begin{tabular}{lcc}
\hline Period & AUC mean & AUC SD mean \\
\hline $2041-2060$ & 0.913 & 0.023 \\
$2061-2080$ & 0.896 & 0.002 \\
$2081-2100$ & 0.907 & 0.021 \\
\hline
\end{tabular}

\section{Predicted current potential distribution}

Using ArcGIS 10.8, the map in Figure 3 shows the potential MSD spreading projection for $C$. fimbriata based on observed occurrences and the environmental variables projected by the Maxent model for 2021-2040.

The coastal area in northern Oman showed high suitability for $C$. fimbriata disease distribution. The total area of suitable locations (including less suitable habitat, moderately suitable area, and highly suitable area) was $64,393 \mathrm{~km}^{2}$. The highly suitable areas for C. fimbriata were primarily located along the coast in northern Oman with a presence probability $>0.6$, which was only $5 \%$ of the total area for the training \& histrorical period 1970-2000 (Figure $3)$.

\section{Future climatic distribution scenarios}

The estimated future climate change distributions for C. fimbriata with various climate change projections for the periods of 2021-2040, 2041-2060, 2061-2080, and 20812100 are presented in Figure 4. The results showed that there was an increase of $5 \%$ between the total number of suitable habitats in 2021-2040 and those predicted for 2081-2100 (Figure 4). Compared with the 2021-2040 distribution, the total area of the moderately suitable regions for $C$. fimbriata under the three climatic scenarios for the periods 2021-2040, 2041-2060, 2061-2080, and 2081-2100 would increase by $1.44 \%, 0.52 \%$, and $0.33 \%$ respectively. In contrast, the total area of the highly suitable habitats would increase by $1.7 \%$, $4.5 \%, 4.41 \%$, and $5 \%$ respectively (Table 3 ). Under the scenarios for 2021-2040, 2041-2060, 2061-2080, and 20812100 , the areas of the less suitable regions would decrease by $-1.97 \%,-5.95 \%,-4.93$, and $-3.09 \%$, respectively, and the areas of the unsuitable regions would decrease by $16 \%$ (Table 3).

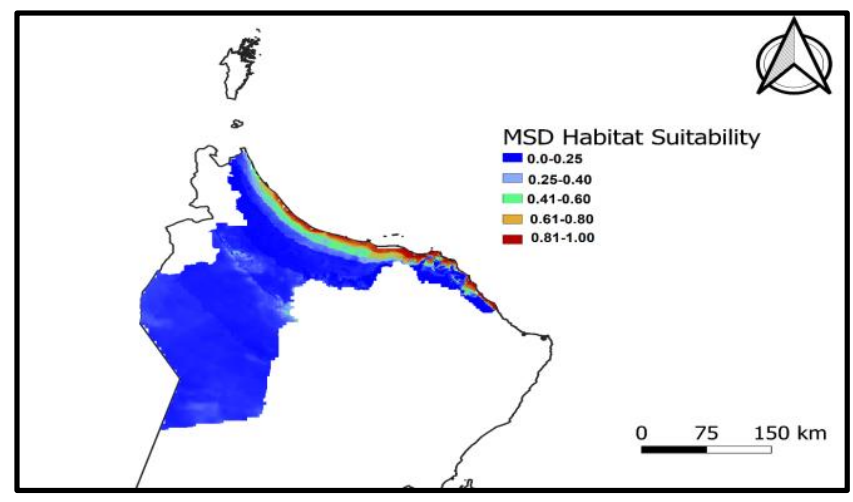

Figure 3. Suitable climatic distribution of $C$. fimbriata in north Oman for the historical period 1970-2000. The MaxEnt model was trained with this historical period. The blue color $(0.0-0.2)$ and red color (0.8-1.0) show the least and most suitable locations for $C$. fimbriata, respectively. 
Table 3. Predicted suitable areas for $C$. fimbriata in future Climatic Conditions

\begin{tabular}{|c|c|c|c|c|c|c|c|c|c|c|}
\hline \multirow{2}{*}{$\begin{array}{l}\text { Scenarios } \\
\text { Period }\end{array}$} & \multicolumn{5}{|c|}{ Predicted area $\left(\mathbf{k m}^{2}\right)$} & \multicolumn{5}{|c|}{$\begin{array}{c}\text { Rate increase/decrease (\%) compared to } \\
2020-2040\end{array}$} \\
\hline & UH* & PSH & MSH & SH & HSH & UH & PSH & MSH & SH & HSH \\
\hline 1970-2000 (Historical \& Training) & 57822 & 1507 & 1850 & 1081 & 2133 & & & & & \\
\hline 2021-2040 & 7916 & 287 & 172 & 175 & 167 & $-1 \%$ & $-0.95 \%$ & $0.89 \%$ & $-0.33 \%$ & $1.40 \%$ \\
\hline 2041-2060 & 2422 & 49 & 36 & 12 & 0 & $-6.35 \%$ & $0.40 \%$ & $1.44 \%$ & $1.20 \%$ & 3.3 \\
\hline 2061-2080 & 2458 & 57 & 61 & 15 & 0 & $-5.07 \%$ & $0.14 \%$ & $0.52 \%$ & $1.10 \%$ & $3.31 \%$ \\
\hline $2081-2100$ & 2426 & 80 & 66 & 19 & 0 & $-3.84 \%$ & $-0.75 \%$ & 0.33 & $0.95 \%$ & $3.31 \%$ \\
\hline
\end{tabular}

* $\mathrm{UH}=$ Unsuitable habitat (0-0.25), $\mathrm{PSH}=$ Poorly suitable habitat (0.25-0.40), MSH= Moderately suitable habitat $(0.41-0.60), \mathrm{SH}=\mathrm{Suitable}$ habitat (0.61-0.80), HSH= Highly suitable habitat (0.81-1.0).

Figure 5 shows the standard deviation (SD) associated with the climatic projections. The SD values quantify the uncertainty of the predictions from the models. It is clear from these figures that predictions of climate projections (farther into the future 2061-2080 and 2081-2100) have more slightly variability (high SD) in habitat suitability when compared with the immediate climatic projection periods (2021-2040 \& 2041-2060).

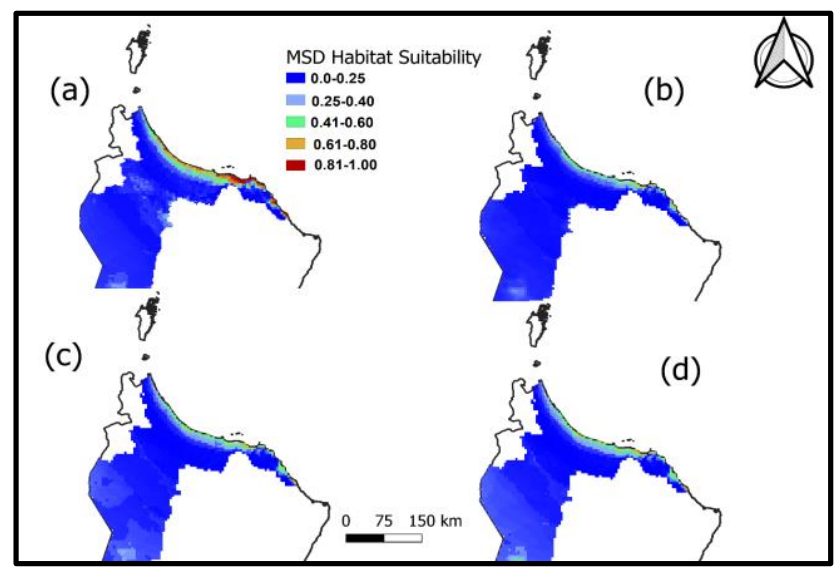

Figure 4. Potentially suitable climatic distribution of $C$. fimbriata under different climate change scenarios in north Oman for the future periods (a) 2021-2040 (b) 2041-2060, (c) 2061-2080, and (d) 2081-2100. The blue color (0.0-0.2) and red color $(0.8-1.0)$ show the least and most suitable locations for $C$. fimbriata, respectively.

\section{Discussion}

This paper is considered as one of the pioneers in investigating $C$. fimbriata distribution in relation to climate change consequences in northern Oman using Maxent modeling. Maxent is widely used in research, primarily because of its ability to provide speedily and thorough outcomes on past, current, and future presence of a specified species (da Silva Galdino et al., 2016). At least two studies have used Maxent to estimate the probable dispersal of many species (De Meyer et al., 2010; Solhjouy-Fard et al., 2013). The potential MSD distributions were predicted to change as a direct result of future climate change scenarios (da Silva Galdino et al., 2016). This study projected the probable dissemination of $C$. fimbriata and explored the potential geographic distribution of MSD with various future climatic scenarios. In this paper, the probable spread of $C$. fimbriata is centered on bioclimate variables, with seven leading variables (bio1, bio2, bio13, bio14, bio15, bio19, and elevation) instead of focusing on the other abiotic factors, such as soil and water-type influences and the type of mango tree cultivar (Al-Adawi et al., 2003). Climatic factors are the most crucial elements that contribute to the regeneration and spread of MSD (da Silva Galdino et al., 2016).

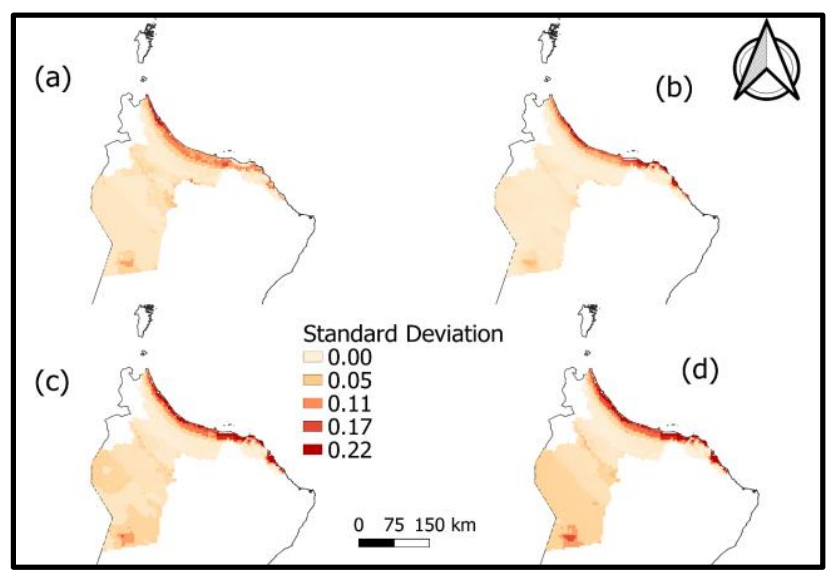

Figure 5. The Standard deviation maps of the species distribution in Maxent for climatic projections (a) 2021-2040 (b) 2041-2060 (c) 2061-2080 (d) 2081-2100.

The model outcomes showed that the highly suitable areas for $C$. fimbriata potentially increased by $3.31 \%$ in 2081-2100, covering an area of about $2234 \mathrm{~km}^{2}$. da Silva Galdino et al. (2016) explained the potential effects of global warming on MSD distributions through expansions and shifts in the species' range. This paper showed that under the projected future climatic scenarios, the distribution for $C$. fimbriata would expand under all projections in 20412060, 2061-2080, and 2081-2100 periods, proving that more areas would exist for MSD invasion. The change was more obvious for the period 2081-2100 than for 2061-2080, and the outcomes predicted by this study were consistent with those of other studies showing the consequences of habitat change under the effects of future climate change (Biber-Freudenberger et al., 2016). Even so, under different 
climatic scenarios, the results did not show the same trend, which might be due to the variation in humidity and temperature that influence $C$. fimbriata spread. In addition, averaging the bioclimatic variables might also have contributed to the uncertainty by creating overlapping results.

As this study provided a spatial mapping for the possible disease distribution in northern Oman, techniques such as integrated approaches or strategies such as the development of hybrid species could abate the spread and also provide an increased resistance to $C$ fimbriata. Other approaches could be, for instance, incorporating pest management policies could help in managing the disease invasion (Al-Adawi et al., 2003). The important maps produced in this study are indicators of the possible establishment of MSD disease and potential areas that are at risk of its invasion. Therefore, the result of this study can be used by decision-makers in preventing the establishment of this disease in the agricultural corridor of Oman. The best defense mechanism is improvement in agricultural policy and governance in crop production and soil management. Moreover, the agricultural land in Oman is composed of mixtures of various crops; as a result, the current spatial distribution of Mango as a specific crop is not mapped or known. However, with Oman being an arid country, the suitable areas for crop production are known which is usually along the lowland of the coastal area. This study will help the farmers to identify the suitable area for mango production and the vulnerable area for disease distribution in current and future climate change scenarios. Since most of Oman's land is not suitable for agricultural practices this type of study is important as it help the farmers and the decision-makers to conserve the suitable agricultural land and to protect their agricultural crops from diseases and from other possible reasons of converting this land to urban land use. Furthermore, one of the challenges in this study was the lack of spatial data on the MSD distribution. However, this study will help in identifying possible sites that could help the decision-makers in mapping and quantifying the potential vulnerable sites and farms.

In conclusion, even though this study indicated possible changes in environmental and climatic conditions, it did not provide definitive predictions. It was important to evaluate the effects of the global climate change scenario on the potential distribution of MSD diseases, because by doing so it provided a helpful understanding of the relationship between the prevalence of MSD and the corresponding environmental variables. This study, therefore, helps to identify areas of potential MSD distribution and to establish operational strategies for managing and inhibiting the future distribution of the disease.

This study was one of the first in providing future projections of $C$. fimbriata in northern Oman. The MaxEnt model was trained with a previous period (1970-2000) and then projected to future climate periods (2021-2040, 20412060, 2061-2080, 2081-2100). The results showed Maxent provided a good representation of MSD pattern and distribution by using data from 15 affected locations and 7 bioclimatic variables in predicting the consequence of climate change on the mango trees. The following conclusions are drawn:

i. Between the period 2081 and 2100, the extent of extremely suitable category for C.fimbriata would increase by $5 \%$ under the projection of climate change for that period.

ii. Climate change consequences on the probable spread of MSD must therefore be considered, primarily to estimate the loss of mango production and to prevent the potential establishment of MSD, as the area of suitable habitat will increase $5 \%$ by 2100 .

iii. This study found that the following bioclimatic variables such as biol (Mean Annual Temperature), and bio2 (Mean Diurnal Range (Mean of monthly (max temp - min temp) and bio14 (Precipitation of Driest Month) contribute significantly to the possible distribution of MSD in northern Oman. The change in future climatic scenarios will foster an outbreak in mango tree diseases. Therefore, strategic planning such as defining vulnerable areas for the protection of mango and conservation initiatives (which can help in minimizing the impacts) should be considered for mango planting farms.

The results of this study would be of immense benefit to decision-makers from the local to national levels, where informed best management practices would be made for sustainable mango production in Oman under a changing climate.

\section{Acknowledgment}

The authors would like to thank Dr. da Silva Galdino for providing the mango sudden decline (MSD) locations in Oman.

\footnotetext{
الملخص

الرحيلي، آمنة، ألابا بولوواده وعلي الصبحي. 2021. تخمين حدوث الموت المفاجىء للمانجو المتسبب عن الفطر Ceratocystis fimbriata تعت https://doi.org/10.22268/AJPP-039.3.215223 ظروف التغير المناخي. مجلة وقاية النبات العربية، 215-215:

تعتبر أشجار المانجو من المحاصيل المهمة لقيمتها الغذائية والاقتصادية العالية. يعد مرض الموت المفاجئ (MSD) من الأمراض الرئيسية التي تهدد أشجار

المانجو في عمان وجميع أنحاء العالم. هدفت هذه الدراسة إلى تحديد المناطق في شمال عمان التي ينتشر فيها فطر Ceratocystis fimbriata المسبب

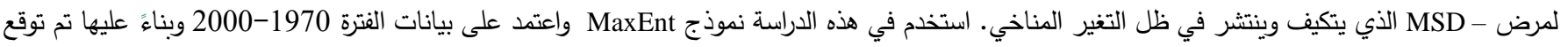

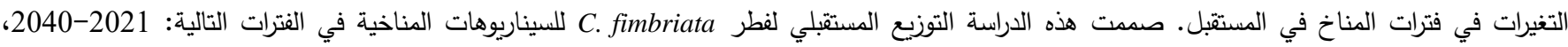
2060-2041، 2061-2080، و 2081-2100. تم في هذه الدراسة تضمين خمسة عشر موقعاً متأثراً بالمرض واستخدام سبعة متغيرات مناخية حيوية. أظهر استخدام
} 


$$
\begin{aligned}
& \text { اختبارات النمذجة قيماً تتراوح بين } 0.896 \text { و } 0.913 \text { (ملاءمة الموائل) مما يمثل نموذجاً جيداً للنتائج. أظهر اختبار jackknife أن متوسط المدى النهاري لدرجة الحرارة }
\end{aligned}
$$

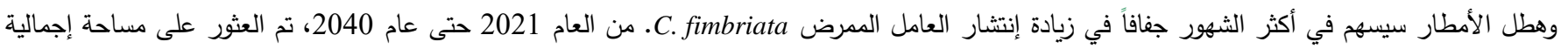

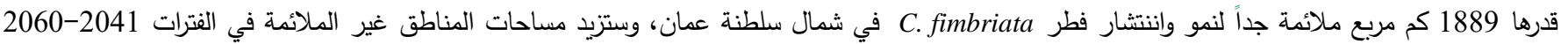

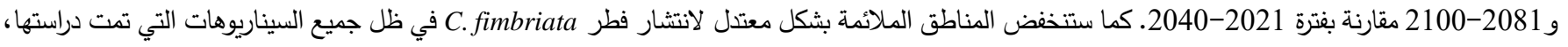

$$
\begin{aligned}
& \text { إلا أن المساحة الإجمالية للمناطق الملائمة مع جميع السيناريوهات ستزداد ما عدا الفترة 2041-2060. ستساعد نتائج هذه البحث في إدارة ومنع مرض الموت المفاجئ }
\end{aligned}
$$

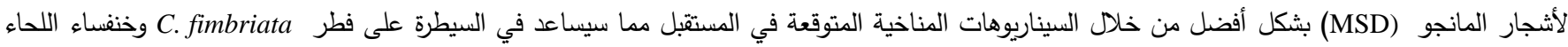

$$
\begin{aligned}
& \text { (Hypocryphalus mangiferae) } \\
& \text { و الحيو انية، وزارة التعليم العالي والبحث العلمي والإبتكار، مسقط الإن 112، عمان. }
\end{aligned}
$$

\section{References}

Al-Adawi, A.O, M.L. Deadman, A.K. Al-Rawahi, A.J. Khan and Y.M. Al-Maqbali. 2003. Diplodia theobromae associated with sudden decline of mango in the Sultanate of Oman. Plant Pathology, 52(3): 419. https://doi.org/10.1046/j.1365-3059.2003.00841.X

Al-Adawi, A.O., M.L. Deadman, A.K. Al Rawahi, Y.M. Al Maqbali, A.A. Al Jahwari, B.A. Al Saadi and M.J. Wingfield. 2006. Aetiology and causal agents of mango sudden decline disease in the Sultanate of Oman. European Journal of Plant Pathology, 116(4): 247-254. https://doi.org/10.1007/s10658-006-9056-X

Al-Subhi, A.M., A.O. Al-Adawi, M. Van Wyk, M.L. Deadman and M.J. Wingfield. 2006. Ceratocystis omanensis, a new species from diseased mango trees in Oman. Mycological Research, 110(2): 237-245. https://doi.org/10.1016/j.mycres.2005.08.007

Anderson, R.P. and Jr.I. Gonzalez. 2011. Species-specific tuning increases robustness to sampling bias in models of species distributions: an implementation with Maxent. Ecological Modelling, 222(15): 2796-2811.

Arauz, L.F. 2000. Mango anthracnose: Economic impact and current options for integrated management. Plant Disease, 84(6), 600-611. https://doi.org/10.1094/PDIS.2000.84.6.600

Biber-Freudenberger, L., J. Ziemacki, H.E. Tonnang and C. Borgemeister. 2016. Future risks of pest species under changing climatic conditions. PloS One, 11(4). https://doi.org/10.1371/journal.pone.0153237

Collins, M., R. Knutti, J. Arblaster, J.L. Dufresne, T. Fichefet, P. Friedlingstein and M. Shongwe. 2013. Long-term climate change: projections, commitments and irreversibility. Pages 1029-1136. In: Climate change 2013-The physical science basis: Contribution of working group $I$ to the Fifth Assessment Report of the Intergovernmental Panel on Climate Change. T.F. Stocker, D. Qin, G.-K. Plattner, M. Tignor, S.K. Allen, J. Boschung and P.M. Midgley (eds.). Cambridge University Press. da Silva Galdino, T.V., S. Kumar, L.S. Oliveira, A.C. Alfenas, L.G. Neven, A.M. Al-Sadi and M.C. Picanco. 2016. Mapping global potential risk of mango sudden decline disease caused by Ceratocystis fimbriata. PLoS One, 11(7): https://doi.org/10.1371/journal.pone.0159450

De Meyer, M., M.P. Robertson, M.W. Mansell, S. Ekesi, K. Tsuruta, W. Mwaiko and A.T. Peterson. 2010. Ecological niche and potential geographic distribution of the invasive fruit fly Bactrocera invadens (Diptera, Tephritidae). Bulletin of entomological research, 100(1): 35-48. https://doi.org/10.1017/S0007485309006713

Evangelista, P.H., S. Kumar, T.J. Stohlgren and N.E. Young. 2011. Assessing forest vulnerability and the potential distribution of pine beetles under current and future climate scenarios in the Interior West of the US. Forest Ecology and Management, 262(3): 307-316. https://doi.org/10.1016/j.foreco.2011.03.036

Eyring, V., S. Bony, G.A. Meehl, C.A. Senior, B. Stevens, R.J. Stouffer and K.E. Taylor. 2016. Overview of the Coupled Model Intercomparison Project Phase 6 (CMIP6) experimental design and organization. Geoscientific Model Development, 9: 1937-1958. https://doi.org/10.5194/gmd-9-1937-2016

Godfray, H.C.J., J.R. Beddington, I.R. Crute, L. Haddad, D. Lawrence, J.F. Muir and C. Toulmin. 2000. Food security: the challenge of feeding 9 billion people. Science, 327(5967): 812-818. https://doi.org/10.1126/science.1185383

Hassan, Z.U., Nazami, N. 2017. Potential risk to mango orchards: mango sudden decline caused by Ceratocystis fimbriata. Pakistan Journal of Phytopathology, 29(1): 181-185. https://doi.org/10.33866/phytopathol.029.01.0330

Li, G., S. Du and Z. Wen. 2016. Mapping the climatic suitable habitat of oriental arborvitae (Platycladus orientalis) for introduction and cultivation at a global scale. Scientific Reports, 6: 30009. https://doi.org/10.1038/srep30009 
McDonnell, R., 2016. Groundwater use and policies in Oman. IWMI Project Report No. 14. Groundwater governance in the Arab World.

Ministry of Agriculture and Fisheries (MAF). 2014 Agricultural Survey, 2012/2013. General Directorate for Planning and Development, Ministry of Agriculture and Fisheries (Arabic).

MRMWR (Ministry of Regional Municipalities \& Water Resources, Sultanate of Oman). 2008. Water Resources in Oman. Available at: http://www.omanws.org.om/images/publications/5465 Water_Atlas_E.pdf

Pearson, R.G., C.J. Raxworthy, M. Nakamura and A.T. Peterson. 2007. Predicting species distributions from small numbers of occurrence records: a test case using cryptic geckos in Madagascar. Journal of biogeography, 34(1): 102-117. https://doi.org/10.1111/j.1365-2699.2006.01594.x

Pereira, R.M., T.V. da Silva Galdino, N. Rodrigues-Silva, R.S. da Silva, T.C. de Souza and M.C. Picanço. 2019. Spatial distribution of beetle attack and its association with mango sudden decline: an investigation using geostatistical tools. Pest Management Science, 75(5): 1346-1353. https://doi.org/10.1002/ps.5251

Phillips, S.J. and M. Dudík. 2008. Modeling of species distributions with Maxent: new extensions and a comprehensive evaluation. Ecography, 31(2): 161175. https://doi.org/10.1111/j.0906-7590.2008.5203.x

Phillips, S.J., R.P. Anderson and R.E. Schapire. 2006. Maximum entropy modeling of species geographic distributions. Ecological Modelling, 190(3-4): 231259.

https://doi.org/10.1016/j.ecolmodel.2005.03.026

Prabhulinga, T. 2017. Maximum entropy modelling for predicting the potential distribution of cotton whitefly Bemisia tabaci (Gennadius). North India Journal of Entomology and Zoology Studies, 5(4): 1002-1006.

Received: April 29, 2021; Accepted: September 20, 2021
Pretty, J., C. Toulmin and S. Williams. 2011. Sustainable intensification in African agriculture. International Journal of Agricultural Sustainability, 9(1): 5-24. https://doi.org/10.3763/ijas.2010.0583

Rosenzweig, C., A. Iglesias, X.B. Yang, P.R. Epstein and E. Chivian. 2001. Climate change and extreme weather events: Implications for food production, plant diseases, and pests. Global Change Human Health, 2: 90-104. https://doi.org/10.1023/A:1015086831467

Rossetto, C.J. and I.J.A. Ribeiro. 1990. Seca da mangueira. XII. Recomendações de controle. Brazilian Journal of Agriculture-Revista de Agricultura, 65(2): 173-180.

Saeed, E.E., A. Sham, A. AbuZarqa, K. Al Shurafa, T. Al Naqbi, R. Iratni and S. AbuQamar. 2017. Detection and management of mango dieback disease in the United Arab Emirates. International Journal of Molecular Sciences, 18(10): 2086. https://doi.org/10.3390/ijms 18102086

Shcheglovitova, M. and R.P. Anderson. 2013. Estimating optimal complexity for ecological niche models: A jackknife approach for species with small sample sizes. Ecological Modelling, 269: 9-17. https://doi.org/10.1016/j.ecolmodel.2013.08.011

Solhjouy-Fard, S., A. Sarafrazi, M. Minbashi Moeini and A. Ahadiyat. 2013. Predicting habitat distribution of five heteropteran pest species in Iran. Journal of Insect Science, 13(116): 1-16. https://doi.org/10.1673/031.013.11601

Swets, J.A. 1988. Measuring the accuracy of diagnostic systems. Science, 240(4857): 1285-1293. https://doi.org/10.1126/science.3287615

World Bank. 2020. Population, total - Oman, Available at: https://data.worldbank.org/indicator/SP.POP.TOTL?1 ocations=OM. Accessed on July 29, 2020.

Zhang, L., B. Cao, C. Bai, G. Li and M. Mao. 2016. Predicting suitable cultivation regions of medicinal plants with Maxent modeling and fuzzy logics: a case study of Scutellaria baicalensis in China. Environmental Earth Sciences, 75(5): 1-12. https://doi.org/10.1007/s12665-015-5133

تاريخ الاستلام: 2021/4/29؛ تاريخ الموافقة على النشر: 2021/9/20 